Article

\title{
Survey of Slaughtered Pigs for Occurrence of Ochratoxin A and Porcine Nephropathy in Serbia
}

\author{
Dragan Milićević $^{1, *}$, Verica Jurić ${ }^{2}$, Srđan Stefanović ${ }^{1}$, Milijan Jovanović ${ }^{3}$ and Saša Janković ${ }^{1}$ \\ 1 Institute of Meat Hygiene and Technology, Kaćanskog 13, 11000 Belgrade, Serbia \\ 2 Department for Animal Sciences, Faculty of Agriculture, University of Novi Sad, Trg Dositeja \\ Obradovića 10, 21000 Novi Sad, Serbia. E-Mail: vjuric@polj.fac.ac.yu \\ 3 Department of Pathomorphology, Faculty of Veterinary Medicine, University of Belgrade, Bulevar \\ Oslobođenja 18, 11000 Beograd, Serbia. E-Mail: milijan@vet.bg.ac.yu \\ * Author to whom correspondence should be addressed; E-Mail: dragan@inmesbgd.com; \\ Tel. +381112651825; Fax: +381112651825
}

Received: 19 March 2008; in revised form: 29 October 2008 / Accepted: 31 October 2008 / Published: 7 November 2008

\begin{abstract}
Samples of blood, kidney and liver were randomly selected from slaughtered pigs $(n=90)$ and analyzed for ochratoxin A by HPLC. In addition, in order to obtain information on the occurrence of nephropathy, histological examinations were carried out. Of the 90 liver samples, $26.6 \%$ contained OTA in the range of $0.22-14.5 \mathrm{ng} / \mathrm{g}$. The incidence of OTA in serum and kidney were very similar $(31 \%, 33.3 \%)$, with a maximum concentration of $220.8 \mathrm{ng} / \mathrm{mL}$, and $52.5 \mathrm{ng} / \mathrm{g}$, respectively. Histopathological examination of kidneys confirmed tubulopathies with edema and cell vacuolization. In addition, hemorrhages and necrosis of proximal kidney tubules' cells were found.
\end{abstract}

Keywords: Ochratoxin A, pig, tissues, nephropathy.

\section{Introduction}

Ochratoxin A (OTA) is a nephrotoxic mycotoxin produced by several species in the Aspergillus and Penicillium genera. These species occur worldwide, as a contaminant of agricultural commodities, especially cereals [1], but also in a variety of other food commodities [2, 3] as a result of poor storage 
of said commodities or poor agricultural practice during drying procedures [4]. OTA is nephrotoxic to all animal species and causes mycotoxicosis in animals, particularly in swine $[5,6]$ and this mycotoxin plays a special role in the genesis of mycotoxic porcine nephropathy (MPN), a common disease in Scandinavia [5]. OTA has been considered as possible cause of the human disease known as Balkan Endemic Nephropathy (BEN) [7]. The toxicological profile of OTA includes teratogenesis, nephrotoxicity and immunotoxicity [8]. Moreover, OTA was classified as being carcinogenic in animals [9-11]. Special attention has been paid to OTA since 1993, when the International Agency for Research on Cancer classified this toxin as a possible human carcinogen (group 2B) [12-14]. Under certain circumstances the levels of OTA in pig blood are of great concern. Hult et al. (1980) demonstrated that the level of OTA in blood is very expressive of the general exposure of the individuals to this mycotoxin and would be a useful tool in diagnosing ochratoxicosis. The high affinity of OTA to proteins, particularly to serum albumin, allows its accumulation in the organs of animals [16]. In fact, animal-derived products and tissues for human consumption may well present OTA residues even if the animal has been nourished with feeds contaminated with low levels of OTA. In many studies, OTA has been detected in pig's blood, kidney, liver muscle and adipose tissue with rather high levels found in animals suffering from porcine nephropathy [6, 17-22], especially in countries of Balkan Peninsula [23-27]. A nephropathy in pigs with characteristic macroscopic changes of the type "mottled or pale enlarged kidneys" has been frequently identified at meat inspection in Serbia, corresponding well with the data found in other countries of the Balkan Peninsula [24].

The purpose of this work was to monitor the presence of OTA in edible tissues of normally slaughtered Serbian swine, and also to evaluate data for the relation between the content of ochratoxin A and pathomorphological changes in kidney.

\section{Results and Discussion}

\subsection{Occurrence, concentration and regional distribution of Ochratoxin A in tissues}

The occurrence and mean concentrations of ochratoxin A in swine serum, kidney and liver are summarized in Tables 1 and 2.

\subsubsection{Ochratoxin A in Serum}

OTA contamination assessment showed that $28(31 \%)$ of the analyzed serum samples $(\mathrm{n}=90)$ were contaminated in a very wide range from 0.22 to $220.8 \mathrm{ng} / \mathrm{mL}$ (mean levels $3.70 \pm 23.59 \mathrm{ng} / \mathrm{mL}$ ). The incidences of OTA and mean level of contamination in the three regions where samples were collected are very different (Table 1), varying between $16.6 \%$ (mean- $0.19 \mathrm{ng} / \mathrm{g}$, Vladimirci) to $43.3 \%$ (mean$2.33 \mathrm{ng} / \mathrm{g}$, Senta). The highest OTA level $220.8 \mathrm{ng} / \mathrm{mL}$ (mean-8.58 ng/mL), with the highest coefficient of variation (4.69) was found in the samples originate from the Bogatic region. Analysing the range of OTA levels in fourteen samples (15.5\%), levels of ochratoxin A ranged from 0.1 to 1 $\mathrm{ng} / \mathrm{mL}$. The concentrations in a further eight samples $(8.8 \%)$ fell between $1-5 \mathrm{ng} / \mathrm{mL}$ while the rest of the samples $(6.6 \%)$ had concentrations greater than $5 \mathrm{ng} / \mathrm{mL}$. The incidences of higher concentrations 
of ochratoxin A ( $>5 \mathrm{ng} / \mathrm{mL}$ ) in serum was similar to those in kidney (6.6 and $5.5 \%$ respectively), while ochratoxin A was greater than $5 \mathrm{ng} / \mathrm{g}$ in only two (2.2\%) liver samples (Table 2).

Table 1. Incidence of ochratoxin A in tissues of slaughtered pigs.

\begin{tabular}{lccccc}
\hline & & \multicolumn{5}{c}{ Serum $(\mathbf{n g} / \mathbf{m L})$} \\
\cline { 3 - 6 } Region & $\mathbf{N}(\mathbf{\%})$ & $\bar{X}_{ \pm \mathbf{S d}}$ & $\mathbf{C . V}$. & Range \\
\hline Vladimirci & 30 & $5(16.5)$ & $0.1 \pm 90.57$ & 2.96 & $0.33-2.56$ \\
Senta & 30 & $13(43.3)$ & $2.33 \pm 6.91$ & 2.96 & $0.24-35.7$ \\
Bogatić & 30 & $10(33.3)$ & $8.58 \pm 40.25$ & 4.69 & $0.22-221$ \\
\hline Total & $\mathbf{9 0}$ & $\mathbf{2 8 ( 3 1 . 1 )}$ & $\mathbf{3 . 7 0} \pm \mathbf{2 3 . 6}$ & $\mathbf{6 . 3 7}$ & $\mathbf{0 . 2 2}-\mathbf{2 2 1}$ \\
\hline & & & Kidneys (ng/g) & \\
\hline Vladimirci & 30 & $8(26.6)$ & $0.42 \pm 1.2$ & 2.96 & $0.18-6.5$ \\
Senta & 30 & $11(36.6)$ & $1.14 \pm 3.3$ & 2.89 & $0.17-17$ \\
Bogatić & 30 & $11(36.6)$ & $2.2 \pm 9.54$ & 4.33 & $0.26-52.5$ \\
\hline Total & $\mathbf{9 0}$ & $\mathbf{3 0 ( 3 3 . 3 )}$ & $\mathbf{1 . 2 6} \pm \mathbf{5 . 8 5}$ & $\mathbf{4 . 6 4}$ & $\mathbf{0 . 1 7 - 5 2 . 5}$ \\
\hline & & & Liver (ng/g) & \\
\hline Vladimirci & 30 & $11(36.6)$ & $0.48 \pm 0.75$ & 1.55 & $0.32-2.2$ \\
Senta & 30 & $4(13.3)$ & $0.84 \pm 2.95$ & 3.51 & $0.56-14.5$ \\
Bogatić & 30 & $9(30)$ & $0.56 \pm 1.17$ & 2.09 & $0.22-5.46$ \\
\hline Total & $\mathbf{9 0}$ & $\mathbf{2 4 ( 2 6 . 6 )}$ & $\mathbf{0 . 6 3} \pm \mathbf{1 . 8 7}$ & $\mathbf{2 . 9 6}$ & $\mathbf{0 . 2 2}-14.5$ \\
\hline
\end{tabular}

N-total number of analyzed samples, n-number of positive samples, $\bar{X}$-arithmetic mean (conc. below LOD are regarded as zero), C.V.-coeff. of variation.

\subsubsection{Ochratoxin A in Kidney}

In contrast, our results showed that the frequency of contamination of OTA was higher in the kidney than in the serum and liver (Table 1). The incidence of ochratoxin A among the three regions where samples were collected varied between $26.6 \%$ (Vladimirci) to $36.6 \%$ (Senta and Bogatić) with a mean contamination frequency of $33.3 \%$. In regard to regional distribution of OTA, the average OTA concentration in positive samples varied between $0.42 \mathrm{ng} / \mathrm{g}$ (Vladimirci) and $2.2 \mathrm{ng} / \mathrm{g}$ (Bogatić) where there is the highest concentration of OTA $52.5 \mathrm{ng} / \mathrm{g}$. The majority of samples (16.6\%) contained OTA at low levels $(0.01-1 \mathrm{ng} / \mathrm{g})$. The concentrations in a ten samples $(11.1 \%)$ ranged between $1-5 \mathrm{ng} / \mathrm{g}$, while ochratoxin A in five (5.5\%) samples was greater than $5 \mathrm{ng} / \mathrm{g}$ (Table 2). In $2.2 \%$ samples of 
kidneys, OTA levels was considerably higher and greatly exceed the permissible levels of this toxins established in Serbia and included those proposed (10 ng/g) by the SCF [33], and JECFA [34].

Table 2. Distribution of ochratoxin A in tissues of slaughtered pigs in the regions where samples were collected.

\begin{tabular}{|c|c|c|c|c|c|}
\hline \multirow[b]{3}{*}{ Region } & \multirow[b]{3}{*}{$\mathbf{N}$} & \multicolumn{4}{|c|}{ Number of samples in the range } \\
\hline & & \multicolumn{4}{|c|}{ Serum } \\
\hline & & $<$ LOD & $0.1^{\mathbf{b}}-1$ & $1-5$ & $>5$ \\
\hline Vladimirci & 30 & 25 & 3 & 2 & 0 \\
\hline Senta & 30 & 17 & 6 & 4 & 3 \\
\hline Bogatić & 30 & 20 & 5 & 2 & 3 \\
\hline \multirow[t]{3}{*}{ Total } & 90 & 62 & 14 & 8 & 6 \\
\hline & & \multicolumn{4}{|c|}{ Kidneys } \\
\hline & & $<$ LOD & $0.01^{\mathbf{b}}-1$ & $1-5$ & $>5$ \\
\hline Vladimirci & 30 & 22 & 5 & 2 & 1 \\
\hline Senta & 30 & 19 & 5 & 4 & 2 \\
\hline Bogatić & 30 & 19 & 5 & 4 & 1 \\
\hline \multirow[t]{3}{*}{ Total } & 90 & 60 & 15 & 10 & 5 \\
\hline & & \multicolumn{4}{|c|}{ Liver } \\
\hline & & $<$ LOD & $0.01^{\mathbf{b}}-1$ & $1-5$ & $>5$ \\
\hline Vladimirci & 30 & 19 & 5 & 6 & 0 \\
\hline Senta & 30 & 26 & 1 & 2 & 1 \\
\hline Bogatić & 30 & 21 & 2 & 6 & 1 \\
\hline Total & 90 & 66 & 8 & 14 & 2 \\
\hline
\end{tabular}

N-total number of analyzed samples, nd-not detectable, ${ }^{b} \mathrm{LOD}$-limit of detection (see Experimental Section).

\subsubsection{Ochratoxin A in Liver}

In the present study, OTA was detected in 24 (26.6\%) out of 90 liver samples with a much lower mean value $(0.63 \mathrm{ng} / \mathrm{g})$ than in kidney $(1.26 \mathrm{ng} / \mathrm{g})$ (Table 1$)$. The majority of samples $(15.5 \%)$ contained OTA between $1-5 \mathrm{ng} / \mathrm{g}$, while ochratoxin A in only two (2.2\%) samples of liver was greater than $5 \mathrm{ng} / \mathrm{g}$ (Table 2). In regard to the regional distribution of OTA, the occurrence of OTA among the regions where samples were collected are different and varied between $13.3 \%$ (Senta) to $36.6 \%$ (Vladimirci), but the mean level of contamination were very similar $(0.48-0.84 \mathrm{ng} / \mathrm{g})$. The highest 
OTA level $14.5 \mathrm{ng} / \mathrm{g}$ (mean OTA $0.84 \mathrm{ng} / \mathrm{g}$ ), with the highest coefficient of variation (3.51) was found in the samples from Senta.

Comparison with other published data for the occurrence of OTA and contamination level was generally not different from other European countries such as Sweden, Poland, and Germany, or in areas of Balkan Peninsula and Canada (Table 3).

The present work indicates that regional variations and seasonal differences were observed. Geographical origin and season were recognized as the main factor influencing the OTA content of tissues when samples of the three different regions were compared. During period December-February the mean content of OTA in serum samples in the investigated regions was significantly different $(\mathrm{p}<$ $0.05)$, while the mean content of OTA in liver samples was highly significantly different $(\mathrm{p}<0.01)$. The regional differences and seasonal variations might thus partially explain the concentration differences in the corresponding formulas, as could differences in the storage condition of feedstuffs. In addition, fluctuations in mould growth and contamination level of cereals may result in seasonal variations in dietary exposure to OTA. The highest mean level of OTA found in Bogatić region, could signal a possible relationship between this region and the Balkan Endemic Nephropathy.

Table 3. Incidence of ochratoxin $A$ in tissues of slaughtered pigs in different countries.

\begin{tabular}{|c|c|c|c|c|c|}
\hline Samples & Country & $\begin{array}{c}\text { Incidence } \\
\% \\
\end{array}$ & $\begin{array}{c}\text { Mean } \\
\text { ppb }\end{array}$ & $\begin{array}{c}\text { Range } \\
\text { ppb }\end{array}$ & References \\
\hline \multirow{10}{*}{ Serum } & \multirow{3}{*}{ Sweden } & \multirow{3}{*}{18} & 6.7 & & [28] \\
\hline & & & & & \\
\hline & & & 9.4 & & [29] \\
\hline & Poland & 38 & & & [30] \\
\hline & Germany & 48.7 & 5.8 & & [3] \\
\hline & France & 2 & & up to 6 & [40] \\
\hline & Romania & 98 & 2.43 & up to 13.4 & [25] \\
\hline & Bulgaria & 100 & 60.9 & & [24] \\
\hline & Canada & 36 & 14 & & [32] \\
\hline & Serbia & 56.6 & 2.91 & $2.5-33$ & [26] \\
\hline \multirow{2}{*}{ Kidney } & Germany & 41.9 & 0.43 & & [41] \\
\hline & Serbia & 41.6 & 3.12 & & [27] \\
\hline \multirow{3}{*}{ Liver } & Germany & 17 & 0.07 & & {$[22]$} \\
\hline & Romania & 75 & 0.16 & & {$[25]$} \\
\hline & Serbia & 46.6 & 2.88 & up to 19.5 & [27] \\
\hline
\end{tabular}

With regards to a consumer safety point of view, the literature contains several studies investigating the ration between the levels of OTA in pig kidneys and pig meat [20, 25, 35, 36, 39]. A contamination level for the entire carcass at $25 \mathrm{ng} / \mathrm{g}$ pig kidney should secure that the level in meat do not exceed 10 $\mathrm{ng} / \mathrm{g}$, based on the estimation that the OTA level in pig meat is approximately $40 \%$ of the level in pig 
kidney. The ration "content in meat/content in kidney" varied between 10 and 90\%, and can depend on many factors, e.g. the content of OTA in feed, feeding period, feeding in relation to time of slaughtering. The results from these survey indicated that there was a low correlation between the OTA level in serum and liver as well as in the OTA level in kidney and liver ( $r=0.319$ and $r=0.341$, respectively) while the strongest correlation was found between the OTA level in serum and in kidney $(\mathrm{r}=0.973)$. A similar correlation was found by [39]. The effects of OTA appeared to be longer-lasting than those of other mycotoxins, and possessed cumulative feature. Comparison the data obtained in this trial with other recently published data for the occurrence of OTA in pig edible tissues shows that the found levels are comparable with levels in other European countries [24, 39, 40]. However, it should be remembered when comparing data that factors such as climate conditions during harvest, practices for grain/feed storage etc have influence on the ochratoxin A level in edible tissues. The data obtained in this trial show it should be raises some concern for the livestock industry.

\subsection{Pathomorphology examination}

\subsubsection{Gross pathology}

In all 90 pigs were slaughtered during the study period. Kidneys which were submitted to the laboratory were pale, swollen and enlarged and change in color from the normal mahagony to tan, as follows: 43 (47.7\%) had "mottled or pale kidneys", while 27 (30\%) were enlarged (Figure 1) and 11 $(12.2 \%)$ was smaller than normal. The only other macroscopic lesion in few cases was a small greywhite foci on the kidney surface. No obvious difference was observed between the right and left kidney. No significance changes were seen in other organs.

Figure 1. External surface of a case of "mottled enlarged kidneys" (A) (second and fifth kidney dorsal aspect), and (B) normal sized kidneys, except for the third.
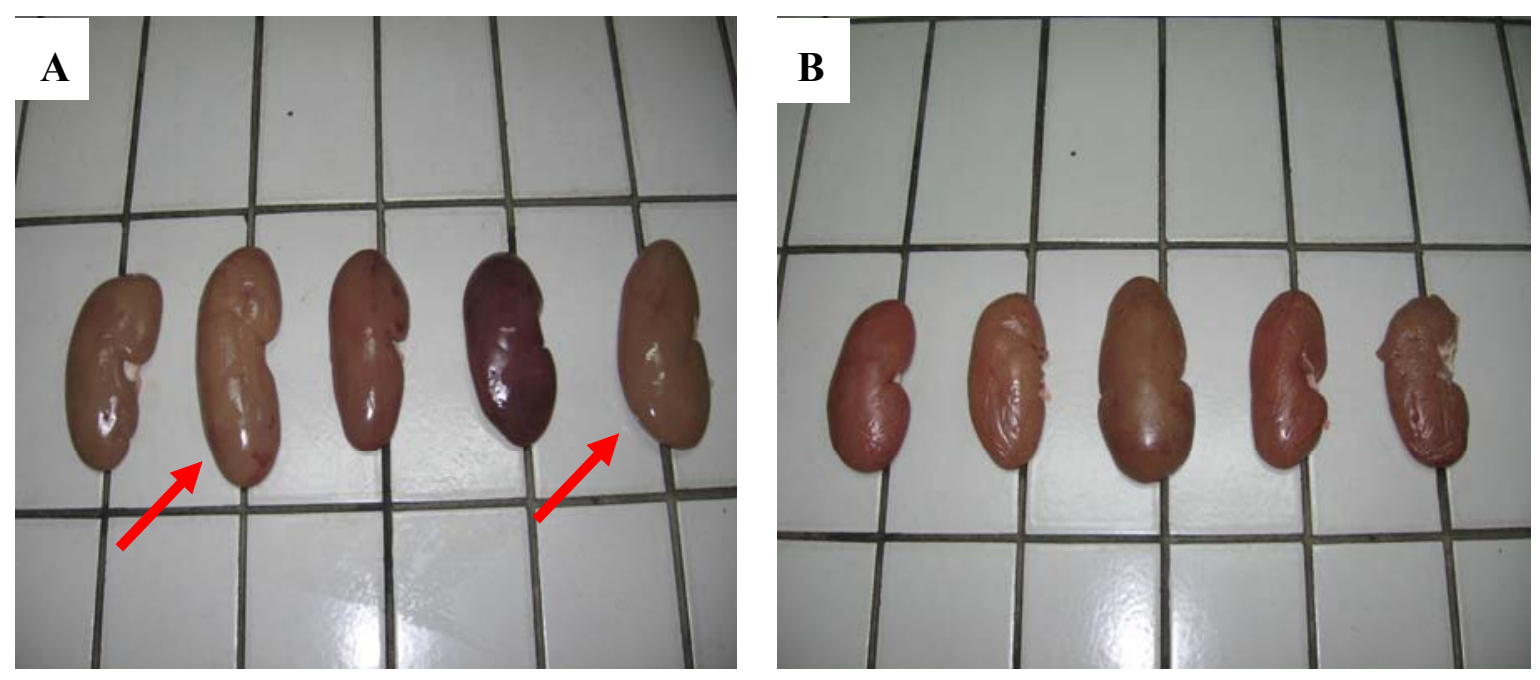


\subsubsection{Histological examination}

Histological examination showed two types of changes: degenerative - affecting epithelial cells in some proximal tubules of pigs, and proliferative changes in the interstitium (Figure 2). The major renal histopathological changes were mainly in the epithelium of proximal tubules. Dystrophy (moderate to marked degenerative changes, Figure 3A), swelling, vacuolization and fatty changes, were the main changes in the tubular epithelial cells. The majority of glomeruli exhibited mild or moderate exudates in Bowman's capsular spaces as well as hypercellularity of vascular loops. In addition vascular changes expresed as a hyperaemia of blood vessels, moderate to marked hemorrhages of some renal cortical regions occurred occasionally (Figure 3D). In the interstitium of some renal cortical regions, there was limited proliferation of connective tissue (Figure 3B) and focal infiltration of mononuclear inflammatory cells which was sometimes accompanied by small granuloms. These results have also been reported in other papers [24, 42-46].

Figure 2. Summary of histological findings $(\mathrm{PH})$ of renal tissues and incidence of OTA in kidney from slaughtered pigs $(n=90)$. Necrosis of proximal tubules' cells (1), hypercellularity of vascular loop (2), vascular changes (3), exudat in Bowman's space (4), focal interstitial nephritis (5), dystrophy of proximal tubules' cells (6), swelling of proximal tubules' cells (7), renal hemorrhages (8), fatty changes of proximal tubules' cells (9).

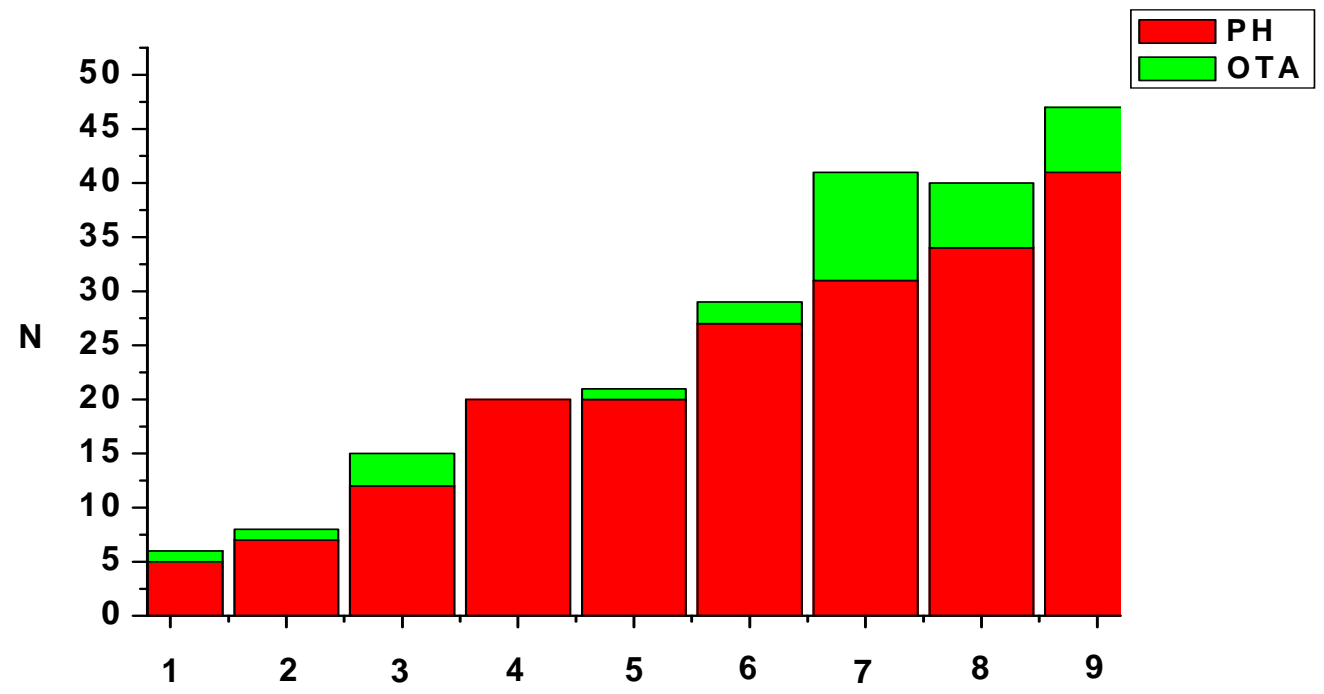

OTA analysis of the kidneys samples where degenerative changes of moderate to marked cloudy swelling were seen revealed the incidence of OTA in $32.2 \%$ samples at concentrations levels up to $52.5 \mathrm{ng} / \mathrm{g}$ (Figure 2). Additionally, vascular changes as well as fatty changes were observed in six kidneys of pigs were ochratoxin A detected up to $6.5 \mathrm{ng} / \mathrm{g}$, while focal interstitial fibrosis and necrosis of proximal tubules' cells were only seen in one kidneys of pigs were ochratoxin A detected up to $52.5 \mathrm{ng} / \mathrm{g}$. In comparison, the lesions produced by higher OTA levels were more severe and widespread, including degeneration, atrophy, glomerular swelling and sclerosis and interstitial nephritis (Figure 2). 
Figure 3. Dystrophy and vacuolar degeneration in the epithelium of proximal tubules' cells (A), focal interstitial fibrosis (B), necrosis of proximal tubules' cells (C) and hemorrhages in cortex (D).
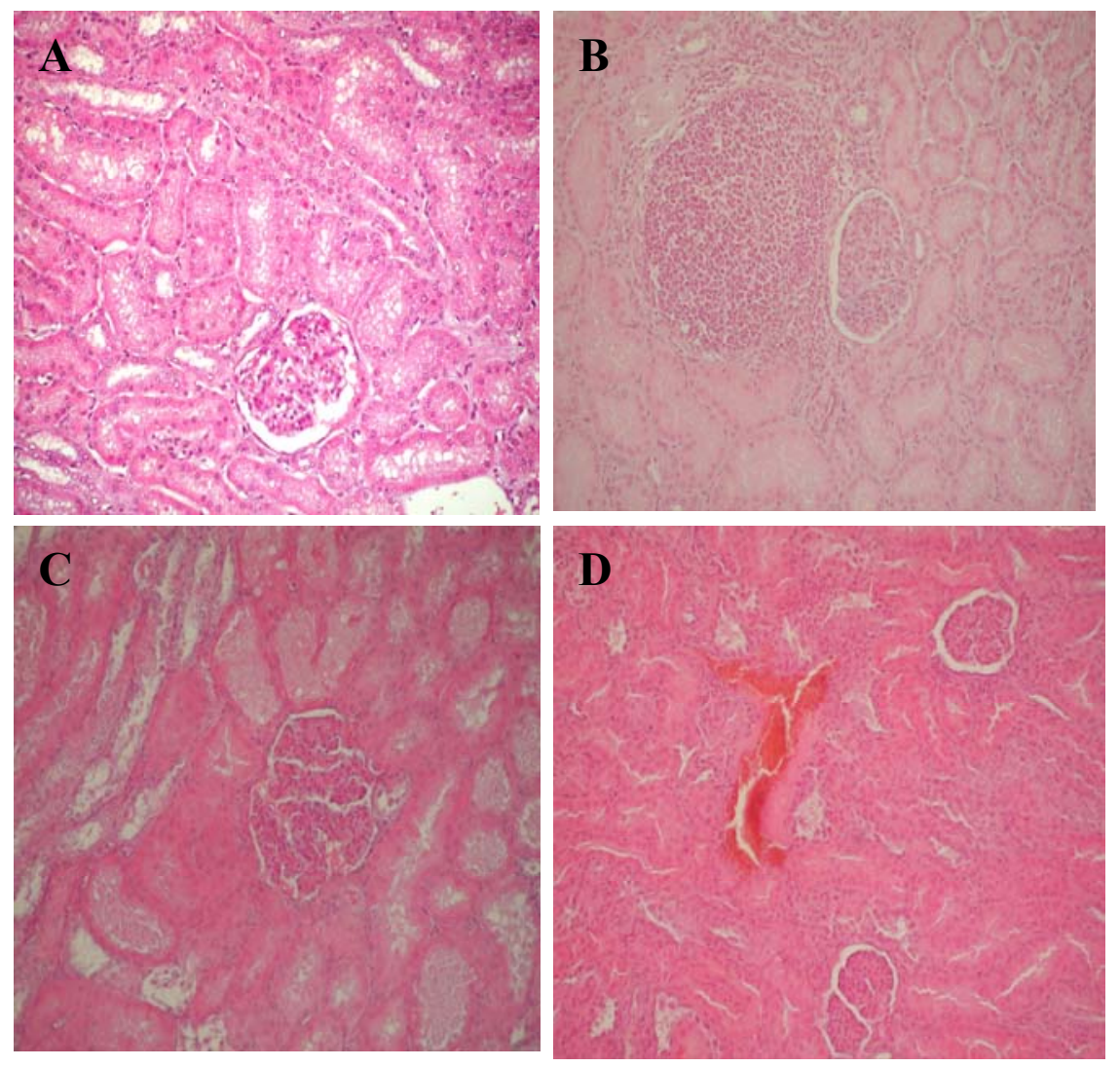

The kidney is the main target of OTA, although it has been shown that possible targets of OTA are the liver, the immune system, and brain cells [47-49]. This high susceptibility of the kidney is, at least in part, the result of OTA-toxicokinetics. Renal blood flow per tissue weight is extremely high, resulting in the delivery of relative large amounts of OTA as compared to other organs. Furthermore, free OTA is secreted in the proximal tubule and subsequently reabsorbed, mainly in the proximal straight tubule, the thick ascending limb of the loop of Henle and the collecting duct [50-56]. Mechanisms involved in reabsorption are, e.g., $\mathrm{H}+$-dipeptide-cotransporter(s) and non-ionic diffusion $[52,55,56]$. These toxicokinetic features result in an accumulation of OTA in renal tissue, where the highest concentrations have been detected in the papilla and the inner medulla [57]. The inhibition of protein synthesis and the damaged energy production in the mitochondria could be considered as the most important factors for degenerative changes in the epithelial cells of proximal tubules where ochratoxin A was detected [58]. While agreeing that the most important toxicological target of OTA in the pig is the kidney, the principal descriptions of the pathology of MPN vary considerably with respect to some other details, and according to the dosing regime and the duration of OTA exposure. Enlarged kidneys are indicative of renal inflammation and proliferative lesions following chronic exposure to OTA $[24,46]$. In the present study no association was found between OTA contamination and kidney weight. Twelve (28\%) out of 43 "mottled or pale kidneys" samples were found to contain OTA, whereas that in the enlarged kidney was $44.4 \%$ in the range $0.17-52.5 \mathrm{ng} / \mathrm{g}$. However, the average concentrations of OTA in some feeds for pigs in Serbia (up to $0.25 \mathrm{mg} / \mathrm{kg}$ ) were substantially 
lower than the 1-2 ppm required to reproduce the classical MPN reported in Denmark. Also, pigs may well contain ochratoxin A in high amounts without any macroscopic chances of the kidneys, as it may take several weeks on ochratoxin A contaminated feeding before porcine nephropathy develops.

Many studies on the role of environmental and host factors have been carried out to elucidate the aetiology of both diseases (BEN and MPN). Such factors include heavy metals [59-62] and other minerals [63], bacteria, leptospira, viruses [64, 65], fungal toxins and, recently, Pliocene lignite's [66], but much stronger evidence support the hypothesis that BEN and MPN have mycotoxic aetiology. It seems, therefore, that MPN observed in Serbia may have a multitoxic aetiology, because it cannot be explained by the concentration of OTA alone. The lack of a strong correlation among histopathological changes and incidence of OTA in kidney (33.3\% kidneys samples were positive, at levels ranging up to $52.5 \mathrm{ng} / \mathrm{g}$ ) found in our trial might thus explain the result of OTA-toxicokinetics as well as possible synergism between OTA and other nephrotoxic mycotoxins or compounds which enhance the toxicity of OTA. Such synergism between OTA and other mycotoxins under field conditions may be responsible for the MPN in Serbia, associated with relatively low mean contamination by OTA in feed. The production of multiple toxins by one or several fungi [67], as is sometimes the natural situation, presents a problem that has not been sufficiently investigated. Considering the similarities with the frequency and levels of OTA reported in other countries, it seems that OTA in Serbian slaughtered pigs represent a particular situation.

The timely diagnosis of disease during the meat inspection at slaughterhouses is very important. The Serbian control system for content of OTA in pig kidney is not yet established, and can be regarded as a lack from a consumer safety point of view. However, the actual concentration in pork is generally very low and hence for the consumer the contribution to the total intake of ochratoxin A from pig products is very small compared with other sources [68]. The values are far below the Acceptable Daily Intake $(A D I)$ of these toxins [33, 34], but high amounts of very hazardous and relatively heat stable OTA may enter in the food chain without any control system. With the present safety evaluation of ochratoxin A [33,34], a residue limit of $10 \mathrm{ng} / \mathrm{g}$ in pork would not be considered satisfactory from a consumer safety point of view.

The prevalence of mycotoxin-induced nephropathy is still unknown, and epidemiological studies must be carried out on a large scale in livestock population where ochratoxin A levels in feed are high, as they are also relevant for the understanding of human nephropathies.

\section{Experimental Section}

\subsection{Reagents}

OTA (benzene free) were purchased from Sigma-Aldrich Chemie GmbH. Stock concentrated solution was prepared in toluene-acetic acid $(99: 1 \mathrm{v} / \mathrm{v})$ at final concentration of $1 \mathrm{mg} / \mathrm{mL}$ and stored at $-20{ }^{\circ} \mathrm{C}$, protected from light. The OTA working solution was prepared by diluting the stock solution with toluene-acetic-acid $(99: 1 \mathrm{v} / \mathrm{v})$ to $\sim 10 \mu \mathrm{g} / \mathrm{mL}$. The actual concentration of OTA was calculated using UV spectrophotometer set at $333 \mathrm{~nm}(\varepsilon$ 5,550). After suitable dilutions in water-methanol-acetic acid $(50: 49: 1 \mathrm{v} / \mathrm{v} / \mathrm{v})$, the working solution was used to prepare the external calibration curve. A 
working standard OTA for HPLC was prepared daily just before starting the injection of a series of samples. Other reagents were HPLC grade. All other chemicals were reagent grade or chemically pure.

\subsection{Sample collection}

During six month period (September 2006/February 2007), samples of blood, kidney and liver from each animal were collected from healthy slaughtered pigs $(n=90)$ originating from three different regions of Serbia where there is a significant swine industry. Slaughtered pigs were randomly sampled in the slaughterhouse during meat inspection. Serum samples were collected from each studied farm and liver and kidneys of corresponding animals. About $50 \mathrm{~mL}$ blood/pig was sampled when slaughtered pigs were bled by jugular puncture. Blood samples remained at room temperature for $24 \mathrm{~h}$ to allow clotting to occur, and were then centrifuged at 3,000 $\times g$ for $20 \mathrm{~min}$. Serum was decanted and stored at $-20{ }^{\circ} \mathrm{C}$ prior to analysis. About $100 \mathrm{~g}$ of liver and whole kidney were sampled from each pig. After cutting pieces of kidney for histological examination, the rest of sample was homogenized and stored at $-20{ }^{\circ} \mathrm{C}$ before analysis. No preservatives were added. For microscopic examination kidney samples were fixed in 10\% neutral buffered formalin. and absolute alcohol for 5 to 7 days, processed by routine methods, sectioned at 5-8 $\mu \mathrm{m}$, and stained with haematoxylin and eosin (HE) for light microscopy.

\subsection{Extraction and clean-up for ochratoxin analyses}

\subsubsection{Extraction and clean-up for ochratoxin analyses from serum}

Serum $(0.8 \mathrm{~mL})$ was extracted according to Curtui and Gareis [25] with $15 \%$ trichloroacetic acid $(0.2 \mathrm{~mL})$ and dichloromethane $(1 \mathrm{~mL})$ by vigorous vortexing for $30 \mathrm{~s}$ in a $2 \mathrm{~mL}$ safe-lock polypropylene conical-bottom centrifuge tube. The mixture was allowed to stand for $24 \mathrm{~h}$ at room temperature, and then centrifuged at $14,000 \times \mathrm{g}$ for $10 \mathrm{~min}$. The lower dichloromethane phase was carefully withdrawn by a Pasteur pipette and transferred to a $1.5 \mathrm{~mL}$ safe-lock polypropylene conicalbottom centrifuge tube. The acidic phase and the compact precipitate layer formed between the two phases were re-extracted with dichloromethane $(0.5 \mathrm{~mL})$ for $30 \mathrm{~s}$ on a vortex mixer and then centrifuged for $5 \mathrm{~min}$ at $14,000 \times \mathrm{g}$. The pooled dichloromethane extract was evaporated to dryness at $40{ }^{\circ} \mathrm{C}$ under a gentle nitrogen flow. The remaining residue was dissolved in methanol $(80 \mathrm{~mL})$ and transferred to a $300 \mu \mathrm{L}$ HPLC vial. The limit of detection (signal/noise: $3 / 1$ ) was estimated at $0.1 \mathrm{ng}$ $\mathrm{OTA} / \mathrm{mL}$, and recoveries was $95 \%$.

\subsubsection{Extraction and clean-up for ochratoxin analyses from kidney and liver}

Kidney and liver analyses were performed by the method of Matrella et al. [69], which briefly includes a double extraction with acidic ethyl acetate. The organic phase was removed and extracted with $0.5 \mathrm{M} \mathrm{NaHCO}_{3}, \mathrm{pH} 8.4$. The aqueous extract was acidified to $\mathrm{pH}-2.5$ with $7 \mathrm{M} \mathrm{H}_{3} \mathrm{PO}_{4} \mathrm{OTA}$ was finally back extracted into ethyl acetate $(3 \mathrm{~mL})$. The organic phase was evaporated to dryness under $\mathrm{N}_{2}$ steam, reconstituted in $150 \mu \mathrm{L}$ mobile phase and a $20 \mu \mathrm{L}$ aliquot injected. The detection limit for OTA 
in organs was $0.01 \mathrm{ng} / \mathrm{g}$ with a $61 \%(\mathrm{C} . \mathrm{V} .=14.5 \%)$ mean recovery from artificially contaminated samples at $3 \mathrm{ng} / \mathrm{g}(\mathrm{n}=3)$.

\subsubsection{Chromatographic conditions (HPLC)}

An aliquot of $20 \mu \mathrm{L}$ for serum samples and $50 \mu \mathrm{L}$ for kidneys and liver samples were injected onto a Waters Symmetry Shield RP (Reversed phase) 18, high pressure liquid chromatography column (length and inner diameter $150 \times 4,6 \mathrm{~mm}$, particle size $5 \mu \mathrm{m}$ ) on a Waters Alliance HPLC system. The column was eluted with $4 \%$ acetic acid and acetonitrile $(32: 68 \mathrm{v} / \mathrm{v})$ at $25{ }^{\circ} \mathrm{C}$ and a flow rate of 1 $\mathrm{mL} / \mathrm{min}$. Measurements were performed by fluorescence detection at wavelengths of $334 \mathrm{~nm}$ (excitation) and $460 \mathrm{~nm}$ (emission) gains 10. A volume of $10 \mu \mathrm{L}$ was injected for the standards and 20 $\mu \mathrm{L}$ for the samples. For more accuracy, $40 \mu \mathrm{L}$ was re-injected in the case of the samples with an amount of OTA near the detection limit.

3.3.4. Confirmation of Ochratoxin A by liquid chromatography tandem mass spectrometric method (LC-MS/MS)

Analyses of serum, kidneys and liver sample were performed by the methods described above [19, 52]. Sample extracts were evaporated to dryness under a gentle stream of nitrogen and stored at $-18{ }^{\circ} \mathrm{C}$ prior to analysis.

\subsubsection{Liquid chromatography tandem mass spectrometric conditions}

Mass spectrometry was performed by Micromass Quattro II triple quadrupole mass spectrometer and MassLynx software for control and data processing. Electro spray ionization in the positive mode was used. The electro spray capillary was set at $3.2 \mathrm{kV}$ and the cone at $30 \mathrm{~V}$. The ion source temperature was set at $115^{\circ} \mathrm{C}$ and the flow rates for nitrogen bath and spray were $700 \mathrm{l} / \mathrm{h}$ and $55 \mathrm{l} / \mathrm{h}$, respectively. Data were acquired in the multiple reaction monitoring (MRM) modes. The collision energy was $18 \mathrm{eV}$. The transitions reactions monitored by LC-MS/MS were $\mathrm{m} / \mathrm{z} 404 \rightarrow 239$ and $\mathrm{m} / \mathrm{z}$ $404 \rightarrow 358$ daughter ion of the ochratoxin A.

\subsection{Statistical analysis}

Descriptive statistics of the data set were performed with a standard programmed and included arithmetic mean, standard deviation, coefficient of variation, minimum, maximum. Statistical differences in the mean levels of OTA contamination across the three groups of positive samples were determined by one-way ANOVA $(p<0.05)$. Significance was set at $\mathrm{p}<0.05$.

\section{Acknowledgements}

The research has been supported by Institute of Meat Hygiene and Technology, Belgrade. We are grateful to Dr. Lazar Turubatović, Director, and other personnel of Department of Food Quality and Department of Residues for their understanding and support to veterinary development. 


\section{References and Notes}

1. Kuiper-Goodman, T.; Scott, P.M. Risk assessment of the mycotoxin ochratoxin. A. Biomed. Environ. Sci. 1989, 2, 179-248.

2. Bauer, J.; Garies, M. Ochratoxin A in the food chain. J. Vet. Med. 1987, B34:613-627 (in German).

3. Jorgensen, K. Survey of pork, poultry, coffee, beer and pulses for ochratoxin A. Food Addit. Contam. 1998, 15, 550-554.

4. Moss, M.O. Mode of formation of ochratoxin A. Food Addit. Contam. Supplement 13 1996, 5-9.

5. Krogh, P. Mycotoxic nephropathy. In Advances in Veterinary Science and Comparative Medicine. Academic Press: New York, 1976; Vol. 20, pp. 147-170.

6. Kotowski, K.; Kostecki, M.; Grabarkiewicz-Szczesna, J.; Golinski, P. Ochratoxin A residue in kidneys and blood of pigs. Med. Weteryn. 1993, 49, 554- 556.

7. Pleština, R. Some features of Balkan endemic nephropathy. Food Chem. Toxicol. 1992, 30, 177-181.

8. Petzinger, F.; Ziegler, K. Ochratoxin A from a toxicological perspective. J. Vet. Pharmacol. Ther. 2000, 23, 91-98.

9. Bendele, A.M.; Carlton, W.W.; Krogh, P.; Lillehoj, E.B. Ochratoxin A carcinogenesis in the (C57BL/6J X C3H)F 1 mouse. J. Natl. Cancer Inst. 1985, 75, 733-742.

10. Boorman, G.A. Toxicology and Carcinogenesis Studies of Ochratoxin A (CAS No. 303-47-9) in F344/N Rats (Gavage Studies). National Toxicology Program, 1989; Technical Report 358.

11. Castegnaro, M.; Mohr, U.; Pfohl-Leszkowicz, A.; Esteve, J.; Steinmann, J.; Tillmann, T.; Michelon, J.; Bartsch, H. Sexand strain-specific induction of renal tumors by ochratoxin A in rats correlates with DNA adduction. Int. J. Cancer 1998, 77, 70-75.

12. Walker, R. Risk assessment of ochratoxin: current views of the European Scientific Committee on Food, the JECFA and the Codex Committee on Food Additives and Contaminants. Adv. Exp. Med. Biol. 2002, 504, 249-255.

13. Ochratoxin A. IARC Monogr. Eval. Carcinog. Risks Hum. 1993, 56, 489-521.

14. Pittet, A. Natural occurrence of mycotoxins in food and feeds-an updated review. Revue Méd. Vét. 1998, 149, 479-492.

15. Hult, K.; Hokby, E.; Gatenbeck, S.; Rutquist, L. Ochratoxin A in blood from slaughter pigs in Sweden: Use in evaluation of toxin content in consumed feed. Appl. Environ. Microbiol. 1980, 39, 822-830.

16. Hagelberg, S.; Hult, K.; Fuchs, R. Toxicokinetics of ochratoxin A in several species and its plasma-binding properties. J. Appl. Toxicol. 1989, 9, 91-96.

17. Rutqvist, L.; Björklund, N.E.; Hult, K.; Hökby, E.; Carlsson, B. Ochratoxin A as the cause of spontaneous nephropathy in fattening pigs. Appl. Environ. Microbiol. 1978, 36, 920-925.

18. Josefsson, E.B.G.; Möller, T.E. Heat stability of ochratoxin A in pig products. J. Sci. Food Agric. 1980, 31, 1313- 1315.

19. Langseth, W.; Nymoen, U.; Bergsjo, B. Ochratoxin A in plasma of Norwegian swine determined by an HPLC column switching method. Nat. Toxins. 1993, 1, 216- 221. 
20. Frohlich, A.A.; Marquardt, R.R.; Clarcke, J.R. Enzymatic and immunological approaches for the quantitation and confirmation of ochratoxin A in swine kidneys. J. Food Protect. 1997, 60, 172176.

21. Lusky, K.; Goebel, R.; Tesch, D.; Doberschuetz, K.-D.; Lusky, K.; Haider, W. Sole and combined administration of the mycotoxins OTA, ZEA and DON. Investigations on animal health and residue behavior. Fleischwirtschaft 2001, 81, 98-102.

22. Gareis, M.; Scheuer, R. Prevention of mycotoxin contamination of meat and meat products. Proceedings of International Symposium of Mycotoxicology '99 Mycotoxin Contamination: Health Risk and Prevention Project (Chiba, Japan) Mycotoxins Supplement '99. 1999; pp. 101107.

23. Pepeljnjak, S.; Čuljak, K. Residues of Ochratoxin A in organs of pigs in wider anephropathic area of SR Croatia. Special Publication Academy of Sciences and Arts of Bosnia and Herzegovina Vol. LXXX. Department of Medical Sciences, 1986; Vol. 12, pp. 71-76.

24. Stoev, S.D.; Grozeva, N.; Hald, B. Ultrastructural and toxicological invastigations in sponataneous cases of porcine nephropathy in Bulgaria. Vet. Arhiv 1998, 68, 39-49.

25. Curtui, V.G.; Gareis, M.; Usleber, E.; Martlbauer, E. Survey of Romanian slaughtered pigs for the occurrence of mycotoxins ochratoxins A and B, and zearalenone. Food Addit. Contam. 2001, 18, 730-738.

26. Milićević, D.; Verica Jurić, M.; Mandić, M.; Đorđević Novi Sad. The presence of ochratoxin A residue in blood plasma of slaughtered swine. Matica Srpska Proceedings for Natural Sciences, 2007; Vol. 113, pp. 55-62.

27. Milićević, D. The Presence of Ochratoxin A Residue in Blood plasma, Liver and Kidney of Slaughtered Swine. M.Sc. Thesis, Faculty of Agriculture, University of Novi Sad, 2006.

28. Holmberg, T.; Breitholtz, A.; Bengtsson, A.; Hult, K. Ochratoxin A in swine blood in relation to moisture content in feeding barley at harvest. Acta Agric. Scand. 1990, 40, 201-204.

29. Holmberg, T.; Hagelberg, S.; Lundeheim, N.; Thavelin, B.; Hult, K. Ochratoxin A in swine blood used for evaluation of cereal handling procedures. J. Vet. Med. 1990a, B37, 97-105.

30. Golinski, P.; Hult, K.; Grabarkiewicz-Szczesna, J.; Chelkowski, J.; Szebiotko, K. Spontaneous occurrence of ochratoxin A residues in porcine kidney and serum samples in Poland. Appl. Environ. Microbiol. 1985, 49, 1014-1015.

31. Rosseau, D.M.; van Peteghem, C.H. Spontaneous occurrence of ochratoxin A residues in porcine kidneys in Belgium. Bull. Environ. Contam. Toxicol. 1989, 42, 181-189.

32. Ominski, K.H.; Frohlich, A.A.; Marquardt, R.R.; Crow, G.H.; Abramson, D. The incidence and distribution of ochratoxin A in western Canadian swine. Food Addit. Contam. 1996, 13, 185-198.

33. SCF. Scientific Committee on Food. Opinion on Ochratoxin A. CS/CNTM/MYC/14 final. Annex II to document XXIV/2210/98, European Commission, Brussels, 1998.

34. JECFA. Toxicological evaluation of certain food additives In Proc. Fifty-sixth Meeting of JECFA, WHO Food Additives Series: Geneva, Switzerland, 2001.

35. Krogh, P.; Axelsen, N.H.; Gyrd-Hansen, N.; Hald, B.; Hyldgaard-Jensen, J.; Larsen, A.E.; Madsen, A.; Mortensen, H.P. Experimental porcine nephropathy. Acta Path. Microb. Scand. Sect. A 1974, 246, 1- 21. 
36. Krogh, P.; Elling, F.; Hald, B.; Larsen, A.E.; Lillehøj, E.B.; Madsen, A.; Mortensen, H.P. Timedependent disappearance of ochratoxin A residues in tissues of bacon pigs. Toxicol. 1976, 6, 235242.

37. Patterson, D.S.P.; Roberts, B.A.; Small, B.J. Metabolism of ochratoxins A and B in the pig during early pregnancy and the accumulation in body tissue of ochratoxin A only. Food Cosmet. Toxicol. 1976, 14, 439- 442.

38. Büchmann, N.B.; Hald, B. Analysis, occurrence and control of ochratoxin A residues in danish pig kidneys. Food Addit. Contam. 1985, 2, 193-199.

39. Mortensen, H.P.; Hald, B.; Larsen, A.E.; Masen, A. Ochratoxin A contaminated barley for sows and piglets. Pig performance and residues in milk and pigs. Acta Agric. Scand. 1983, 33, 349-352.

40. Dragacci, S.; Grosso, F.; Bire, R.; Fremy, J.M.; Coulon, S.A French monitoring programme for determining ochratoxin A occurrence in pig kidneys. Nat. Tox. 1999, 7, 167-173.

41. Gareis, M.; Scheuer, R. Ochratoxin A in meat and meat products. Archives of Meat, Fish and Dairy Science 2000, 51, 81-128.

42. Krogh, P.; Axelsen, N.H.; Gyrd-Hansen, N.; Hald, B.; Hyldgaard-Jensen, J.; Larsen, A.E.; Madsen, A.; Mortensen, H.P. Experimental porcine nephropathy. Acta Path. Microb. Scand. 1974, 246, 1-21.

43. Buck, B.W.; Osweiler, D.G. Clinical and diagnostic Veterinary Toxicology, $2^{\text {th }}$ Ed.; Kendall/Hunt: Dubuque, Iowa, 1976; p. 326.

44. Humphreys, D.J. Mycotoxins, U. Veterinary Toxicology, $3^{\text {rd }}$ Ed. BT Comp.: London, 1988; pp. 283-311.

45. Stoev, S.D.;Vitanov, S.; Anguelov, G.; Petkova-Bocharova, T.K.; Creppy, E.E. Experimental mycotoxic nephropathy in pigs provoked by a diet containing ochratoxin A and penicillin acid. Vet. Res. Commun. 2001, 25, 205-223.

46. Stoev, S.D.; Paskalev, M.; McDonald, S.; Mantle, P. Experimental one year ochratoxin A toxicosis in pigs. Exp. Toxicol. Path. 2002, 53, 481-487.

47. Alvarez, L.; Gil, A.G.; Ezpeleta, O.; Garcia-Jalon, J.A.; Lopez, D.C. Immunotoxic effects of ochratoxin A in Wistar rats after oral administration. Food Chem. Toxicol. 2004, 42, 825-834.

48. Aydin, G.; Ozcelik, N.; Cicek, E.; Soyoz, M.; Histopathologic changes in liver and renal tissues induced by ochratoxin A and melatonin in rats. Hum. Exp. Toxicol. 2003, 22, $383-391$.

49. Monnet-Tschudi, F.; Sorg, O.; Honegger, P.; Zurich, M.; Huggett, A. C.; Schilter, B. Effects of naturally occurring food mycotoxin ochratoxin A on brain cells in culture. NeuroToxicol. 1997, 18, 831-840.

50. Gekle, M.; Silbernagl, S. The role of the proximal tubule in ochratoxin A nephrotoxicity in vivo: toxodynamic and toxokinetic aspects. Renal Physiol. Biochem. 1994, 17, 40-49.

51. Bahnemann, E.; Kerling, H.P.; Ensminger, S.; Schwerdt, G. Renal transepithelial secretion of ochratoxin A in the non-filtering toad kidney. Toxicol. 1997, 120, 11-17.

52. Dahlmann, A.; Dantzler, W.H.; Silbernagl, S.; Gekle, M. Detailed mapping of ochratoxin A reabsorption along the rat nephron in vivo: The nephrotoxin can be reabsorbed in all nephron segments by different mechanisms. J. Pharmacol. Exp. Ther. 1998, 286, 157-162.

53. Gekle, M.; Silbernagl, S.; Mildenberger, S.; Freudinger, R. Effect on dome formation and uptake of ochratoxin A in proximal tubule-derived opossum kidney cell monolayers. Cell Physiol. Biochem. 1993, 3, 68-77. 
54. Sauvant, C.; Silbernagl, S.; Gekle, M. Exposure to ochratoxin A impairs organic anion transport in proximal tubulederived OK-cells. J. Pharmacol. Exp. Ther. 1998, 287, 13-20.

55. Schwerdt, G.; Gekle, M.; Freudinger, R.; Mildenberger, S.; Silbernagl, S. Apical-to-basolateral transepithelial transport of ochratoxin A by two subtypes of Madin-Darby canine kidney cells. Biochim. Biophys. Acta 1997, 1324, 191-199.

56. Zingerle, M.; Silbernagl, S.; Gekle, M. Reabsorption of the nephrotoxin ochratoxin A along the rat nephron in vivo. J. Pharmacol. Exp. Ther. 1997, 280, 220-224.

57. Schwerdt, G.; Bauer, K.; Gekle, M.; Silbernagl, S. Accumulation of ochratoxin A in rat kidney in vivo and in cultivated renal epithelial cells in vitro. Toxicol. 1996, 114, 177-185.

58. Stormer, F.C. Ochratoxin A-a mycotoxin of concern. In Handbook of Applied Mycology. Mycotoxins in Ecological Systems, Bhatnagar, D., Lillehoj, E.B., Arora, D.K., Eds.; Marcel Dekker Inc.: New York, USA, 1992; Vol. 5, pp. 403-431.

59. ATSDR. Toxicological profile for mercury. US Department of Health and Human Services, Public Health Service, Agency for toxic substances and disease registry, TP-93:10, 1994.

60. Agency for Toxic Substances and Disease Registry (ATSDR). Toxicological profiles for arsenic, update. 1998.

61. Zalups, R.K.; Lash, L.H.; Advances in understanding the renal transport and toxicity of mercury. J. Toxicol. Environ. Health. 1994, 42, 1-44.

62. Goering, P.L.; Waalkes, M.P.; Klaassen, C.D.; Toxicology of cadmium. In Toxicology of Metals: Biochemical Aspects. Handbook of Experimental Pharmacology, Goyer, R.A., Cherian, M.G., Eds.; Springer: New York, 1995; vol. 115, pp.189-213.

63. Maksimovic, Z.J.; Djujic, I. Selenium deffciency in Serbia and possible effect on health. Biomed. .Environ. Sci. 1997, 10, 300-306.

64. Uzelac-Keserovic, B.; Spasic, P.; Bojanic, N.; Dimitrijevic , J.; Lako, B.; Lepsanovic, Z.; KuljicKapulica, N.; Vasic, D.; Apostolov, K. Isolation of a coronavirus from kidney biopsies of endemic Balkan nephropathy patients. Nephron 1999, 81, 141-145.

65. Uzelac-Keserović, B.; Vasić, D.; Ikonomovski, J.; Bojanić, N. Isolation of a coronavirus from urinary tract tumors of endemic balkan nephropathy patients. Nephron 2000, 86, 93-94.

66. Feder, G.L.; Radovanovic, Z.; Finkelman, R.B. Relationship between weathered coal deposits and the etiology of Balkan endemic nephropathy. Kidney Int. 1991, 40 (suppl. 34), S9-S11.

67. Jørgensen, K.; Larsen, E.H.; Petersen, A.; Lund, K.H.; Hilbert, G.; Andersen, N.L.; HallasMøller, T.; Larsen, J.C. Food Monitoring 1993-1997 Part 2: Chemical Contaminants. Danish Veterinary and Food Administration Food Report 2001; 18.

68. Mantle, P.G.; McHugh, K.M. Nephrotoxic fungi in foods from nephropathy households in Bulgaria. Mycol. Res. 1993, 97, 205-212.

69. Matrella, R.; Monaci, L.; Milillo, M.A.; Palmisano, F.; Tantillo, M.G. Ochratoxin A determination in paired kidneys and muscle samples from swines slaughtered in southern Italy. Food cont. 2006, 117, 14-117.

(C) 2008 by the authors; licensee Molecular Diversity Preservation International, Basel, Switzerland. This article is an open-access article distributed under the terms and conditions of the Creative Commons Attribution license (http://creativecommons.org/licenses/by/3.0/). 